\title{
THE INCLUSION PROCESSES IN THE EXTENT OF WELFARE SECURITY
}

\section{NATURAL AND CONVENTIONAL UNDERSTANDNG OF SOCIAL CONTEXT OF SECURITY}

The very intensive development of security studies did not solve continuous problems in defining some of its objectives in various areas, such as security of social welfare, and its ever-changing nature of knowledge. Considering merits of such predicaments, as always the goal necessary for solution lies in a proper definition of colloquial ambiguous statements - as was already advocated by Plato in his VII letter. For our understanding, this ambiguity implies that various definitions of security are mixed up by convention or by nature of things. The first, are conducive of expanding and deepening scope of significance in value of security, and in identification of its manifestations (Świniarski, 2013: 18-19); the second, points out towards the reductive concepts, or notices mutually exclusive ideas of security. Hence, the conventional factors and definitions are used in different contexts, capturing security in its wider or narrower perspective (e.g.: Lisiecki, 2008: 5-6). And sometimes in its objective, or sometimes subjective dimensions, (see: Gołembski, 2008: 151-155), and sometimes even processual (see: Zięba, 2012: 8); once in relation to the personal sphere, and other times in relation to the public sphere (see: Skorupka, 1985), either personnel and structural or direct and indirect (see: Drabik, 2013). Sometimes it is used in the context of important technical categories (see: Jaźwiński, Ważyńska-Fiok, 1993), including computer sciences (see: Niemiec, Nowak, Graba, 2006), another times in view of useful values and important social needs associated with security of its public (see: Skrobacz, 2012) or social welfare security in general (see: Jagusiak, 2015), etc. The number of various forms relates to interference with their proper communication relationships, where one speaker refers to information in terms of broad meaning of security, whereas its addressee may have in mind its narrow scope.

Such interference is visible in contemporary literature for which, as it seems, a typical understanding of the word meaning and its definition, including some security terminology, grows out of convention. And this convention and its implication, of how to name "security," is not rooted in proper focus on two words, that compose its meaning (without + care). Very often in many political science publications, the meaning of security is based on the indication of the genre differences, that refers rather vicariously to the lack of threats (no + threats). The examples of a such approach, that leaves its root "care" out of security definition, considering security as, for example: lack of worries and fears (Kaczmarek, Skowroński, 1998: 5); “[...] no physical danger (threat) 
or protection against it" (Zięba, 1999: 27); the recognizing of "[...] a sense of fear and insecurity of imperatives that govern live" (Stańczyk, 1996: 16); “[...] freedom of action, which is not accompanied by a sense of danger ... in a particular form of international order" (Jones, 1970: 98). However more inquisitive, the authors try to, in accordance with the rules of classical definition, indicate a difference in species as defined by the nomos of the security, which tends to indicate the type of category. The examples of such efforts are visible in propositions indicating specific understanding in relation to security as:

- reliability (technology and engineering). Security is a kind of a device or a process with specific focus on reliability, trustworthiness, where security implies system cohesion or lack of threats to its dependability, and is defined as lack of threats of potential system failure, or where security is defined by dependability and attest;

- permanence and confidence in the existence and its development and improvement (humanities, social sciences). Security concerns such type of social existence, that generates specific ideas resting on certainty of existence, stability or development and progress, where security is the absence of threats for its continuity; stability or growth and improvement;

- life, its stability and continuity (natural sciences). Security is a formula of life, that specifically aims at conscious unfolding of its continuity, that is, security is the absence of threats to natural renewal of life, its duration and prolongation;

- freedom, harmony and well-being, uninterrupted peace in concord with other people and natural environment (philosophical studies). Security is a fundament for the proper existence in the universe of any nurture, peculiar to human and natural environment, or where life extends the unity of self into communal unity [peace (coexistence)]: with God, other people and ourselves and nature, or security is the absence of threats to the peace in its multidimensional unity;

- health, property possession and well-being, confidence in tomorrow, etc. (welfare security). Security is a healthy life leading to wealth or prosperity with belief in certainty of existence, or in short, it is living without threats to health, possession and well-being, with confidence in continuity of those on daily bases, because of own abilities or because of State assistance;

- no threat to unity, challenges and opportunity (social science). Security belongs to every existence that specifically aim at security as a final harmony; or: security is an existence in itself, expressing itself by challenges and the opportunities associated with those, and leading to elimination of threats (see: Świniarski, 1997; Stańczyk, 1999: 4; Stownik, 1996: 14; Lisiecki, 2008: 8-9; Rosa, Taylor-Rzeszutko, Kubiak, 2010);

- "four freedoms" (international studies). Security is the (new) international governance, resting specifically on the "four freedoms," two "from" and two "to" - [freedom from hunger, and terror (fear); freedom to: free speech, also in print and other medias, and freedom to religion, or own beliefs] (Roosevelt, 2006); in addition: security is that international governance value, interrelated with these four basic freedoms (of liberty), as in its spatial form is represented by free movement of goods, services, capital and people;

- protection of the existential necessities of human life, assurance of the basic requirements for proper individual growth (physical and spiritual) and the realization 
of aspiration for good life by creating healthy conditions for work and learning, with medicine and pension guarantees (see: Skrabacz, 2012).

Once there was an acceptable definition of existential security found, in accordance to its social dimension, it was then that, the term of social security became a symbolic value for security understood as protective shield, in narrow or wide spectrum of defense for the existential basics of human life. The perspective on social security definition has its wide and narrow versions. The first understands social security as a condition of life posing no threats to the individuals in society, while the second is embedded and characterized by American legislation process (the Social Security Act of 1935, and other with changes) indicating that the purpose those "social security acts" is helping the old, the invalids, and the unemployed. Those designates were incorporated by the International Labor Organization, defining the term "social security" in reference to: social welfare, social assistance, family benefits, and benefits financed from general revenue (see: ibid.).

At the initial generalization, it can be accepted that, in the broadest application of studies on security, done by the social sciences and humanities, its ontological value rests on activities coinciding with: existence, survival, unity, harmony, identity, independence, peace, well-being, development and protection of basic prerequisites for human life. Meeting those requires effort which energizes life involved in resistance to external natural factors, threats and adversities, with potential power to threaten any of the above. Becoming the necessities for human life - as says Michel Foucault, its opposites [...] came to be called "threats" (Foucault, 2010: 30). The need to prevent occurring dangers and associated fears, designates the conventional meaning found in the nomos of "security," which stems out of philosophical grounds of its development, ideology and politics of liberalism - as is argued by Foucault. Liberalism promotes freedom, including such types of freedom, as freedom from fear, terror and hunger and misery, since those threats are the main enemies of liberty and human rights, and apply to the individuals, social groups, large communities, States, concordat of States, and the whole international system. (Zięba, 1999: 27). However, as is pointed out by Foucault: "one of the most important effect of liberalism [...]. [Was that] in the 19th century there appear... the whole new sets of cultural risks [...] the ubiquitous and commonly inoculated general fear of threats ... this is, in a sense, the condition or psychological and cultural internal correlative nature of liberalism" (Foucault, 2010: 90-91). The liberal culture created risks to traditional natural understanding of the human needs, in context of security and threats visible as two forces, creative and destructive, of social order and energy.

Franz-Xaver Kauffmann defines threats as "possible occurrence of one of the negative value phenomena" (Foucault, 2010: 28). And the Swiss political scientist Daniel Frei by analyzing the subjective and objective aspects of the threat formulated synthetic, deontic model explaining security in symmetry to possibility of threats: (1) real (2) slightly exaggerated (obsessive) (3) serious (4) genuine (Fehler, 2002: 166-167). And finally, Joseph S. Nye (Nye, Keohane, 1977) distinguishes two possible meanings within the nomos of "security," namely: negative and positive. In the first meaning - negative security is treated (conventionally) as "no threats." This is the approach focused on analyzing the individual will to resist potential threats, as based on creating 
a social need of subjective focus towards the protection and defensive means against threats for its essential internal values. The second one is wider in scope and definition. It finds the objective values of a subject in essence of analysis, adhering context of description to free and creative activities, independent of others. The possibility of such a process is found in free growth that occurs naturally, when it is not constricted by threats to its expansion. Semantically it implies growth without help (being without external custody or control). In other words: the first approach defines security as opposed to threats (security is the lack of threats), and the second one examines the self-creative potential of being (security is freedom, and the personal situation of the activity of a self) (see: Nye, 2009). At the same time Józef Kukułka differentiates three dimensions of security: of the entity, of the objects, and of the processes. In the interpretation of the above by Ryszard Zięba, he correlates the first one with assurance of existence and survival of the entity, the assurance of its possessions and development, and acceptance of the processual changes within subjective and objective realms of security (see: Finch, 1999: 30).

In conclusion thereof, it should be noted that the concept and its name, the meaning of the word and its expressions, do not always accurately present the range of meanings associated with definitions of "security," and the distinctions are not always sharp, not to mention the inflation of associations. This is observed among others by Jerzy Stańczyk (Stańczyk, 2016: 15). And important reason for variations is the discrepancy between the etymology of security and the modern range of its expression, with weight put on its negative connotation. One can even argue that we are observing increasing distance between the two - historical and modern - etymological values. In the historical case, the word denotes primary activity leading to changes in secondary, yet contemporary terms, allowing communication of new meaning of security, forgetting the initial. The context of security is poly-semantical, that is pragmatical, connecting activity and its value in one explanation. In such a case, the etymology of "security" may disturb its value within the contemporary content, mixing it with conventional definitions, and may even lead to confusion (e.g.: Cackowski, 1989: 25). The etymology of security is a complex of two meanings (without + care) but suggests that the word refers to a situation in which there is no need for participation of custody - as the definition is rather widely accepted in the dictionary forms, and in the literature on a subject of security, that this name refers to a situation in which there are no threats, natural or men made.

\section{TOWARDS A NATURAL UNDERSTANDING OF WELFARE SECURITY}

The literature on security is rich, but written mainly from the perspectives of social sciences, and, as many involved with security studies noted, often gives the simple and convenient, yet misleading or irrelevant explanation, pointing straight forward off the tracks, in view of contemporary phenomena of security, that needs a more detailed description than such as the following: "The focal understanding of the term security is connected to the Latin value of securitas - security - simplest etymological base for various other definitions, and consists of two parts: sine (without) and cura (care, worry, 
fear)" (see: Gołaś, 2013). In such a perspective "security" is understood as a state free of fear and stress (Kaczmarek, Skowroński, 1998: 5). The error of such reasoning putting so much weight on etymology lies in false acceptance of Latin values in sine and cura, where, as a compound word sinecure, it is closer to meaning exemplified by Polish word synekura, than the English security (from Lat. securitas). This is the connotative error, of convenience and free association, in comparison to contemporary connotation of semantic value adhering to observed phenomena, in a conscious observation of its nature, of material evaluation of its appearing forms, relevant to nature of human being. This is for example a problem found in the internet question by Marcin Widawski when he asked about etymology of security and threat (in Polish those two have similar core context meaning), when he rightfully claims that both of those should be connected to word care. The University of Warsaw expert on language and etymology, Krystyna DługoszKurczabowa ${ }^{1}$ agrees with this suggestion concluding, that: secure, that is, without care, implies namely "uncurated" or "uncared." Hence, we have a meaning dissonance between the etymological and real values, and in essence also with conventional expression of the word security, what turns into a vicious circle, as goes the specialist's answer. The meaning of security is twofold, and not necessarily connected to etymological or naturally occurring word (see: Długosz-Kurczabowa, 2010).

However, as it is indicated, the vicious circle can be avoided considering the fact that in the history of the Polish language there are prepositions of old and new version of the same meaning - without or through - in reference to care. The first initially drove out the second in use. This is apparent when we look at the sentence "to ran through the forest." In the oldest version it was used in a sense of "run through the forest without a hat," where word "through" at the same time has a meaning of "without;" later the two meanings in a sentence would be exchanged, and in contemporary times, the proper sentence would have another inversion and conversion of meaning. These problems are visible when we compare the $14^{\text {th }}$ and $15^{\text {th }}$ centuries with the $17^{\text {th }}$ century or later meanings (see: Brückner, 1974: 22-23, 144). In the process of research we can notice, that the range of various meanings and quantity of authors using those interchangeably. Hence, now we have contemporary poly-semantic variations associated with identifying various synonyms as one and the same word, referring to either, an object, or the activity.

If the originally, "secure" meant also a duration "through" time and space, during "lasting of security" (e.g. for three hours, or by a year), the exchange of prefixes within contextual meaning of security, exchanged the value, where the old meaning was converted to its contemporary understanding, where its genre is understood by activity of the State, but not by a phenomenon by itself (see: Brückner, 1974: 406-407). Therefore, the consideration of both a proposition stemming out of old prefixes, without the noun meaning, genetically reflects only the current usage, as found in the first Polishlanguage dictionary, with description of a positive state of being, where later, the same

${ }^{1}$ Krystyna Długosz-Kurczabowa (born April 13, 1940, in Domaszowice, deceased Sept. 14, 2016 in Warsaw) - Polish philologist, with Ph.D. in language studies. She did research on history of Polish language grammar, religious language and Bible translations. She worked at the University of Warsaw, Faculty of Polish Language Studies, in the Institute of Polish Language, Chair of History and Dialectology (Krystyna Dlugosz-Kurczabowa, 2016). 
state entailed, lack of threats. In the old version the meaning signified activity towards something, "caring for," and in the new version, it means "lack of threats."

However, in contemporary Polish language, contrary to the etymological explanation, security is a state of mental forewarning, a psychological and subjective feeling, rather than an objective constancy, or adhering to any law. This concept predisposes a social unit to think in terms of adherence to general value of security being vested in activity of others, creating material planning for unknown substance of threats. Its opposition is considered to be a state of security. That is, not real but heralded security of the whole, where absence of threats means both, security in general or state of possession. With the philosophical question being put: is security a free, uncontrolled state of individual sustainable potential growth or stability, or is it a designed social space, with its tangibles and intangibles, that ontologically determines the prerequisites for the systems coherence and its utility. That condition of the absence of threats and assurance of security, in real and practical terms, can be achieved thanks to those who take care as curators of the realm is understood. One can still conclude that the Polish modern meaning of security in its natural settings, is closer now in its essence of understanding of security as a space of free growth because of elements that are instrumental objectively. Those instruments, even if loosely correlate with the individual life, surely correlate with social life, where the individual values usually have its origins. Such instrumental connection between objects and spatial occurrence, as presented in old and new Polish languages, in reference to objective environment and potential activity within it, is of course the role associated with the natural presentation of both positive, and negative elements occurring within a space of custody. This instrumentality of conditioning the social units within utility of mutual existence, is considered as implementation of life, and thus of the outmost importance. Question is however, which life is natural, the one freely occurring, or the life being created or cured for?

The very similar questions arise when we consider the above in comparison to other Slavic languages, and those, that influenced them in reference to a particular meaning of a given word. In case of the Polish language the word value is given usually by its equivalent in Latin or Greek. The cultural semi-association with a wider spectrum will necessarily direct us towards a local form, but in comparison to the general form, where meaning usually stays the same (see Liddell, Scott, Jones, 1996). In this case, however, looking for etymological connection of security in Greek language, it will be visible only by analogy. In Greek, there is asfaleia, meaning the same, as in Polish security, and there is apelili, similarly signifying threat, however, the Latin source value in Polish is apparent.

As indicated above, at least two dimensions that are present in words describing security, and that are superficially contradictory one to the other, appear also in the Latin language original complex word securitas, securitatis - security. This word consists of the prefix sine - without - or the prefix se - every, oneself and personally, with the word cura - care, attention, supervision, effort, custody - or curo - to care about something, to cure, to heal. Etymologically, therefore, in Latin the term security (Lat. securitas) means something that does not require (Lat. sine - without) care, attention, supervision, effort, cure and custody, or something that is achieved thanks to individual and direct (Lat. se - every) care, attention, effort, control and protection. 
In the English language, however, beside the word security (which also means protection), there exist the related words safety and safe (1. the noun safe meaning a device that protects itself without the need for constant care and supervision, and the adjective safe equivalent to 2. secure and 3. sure). The English word safe originated from the Latin words salvus - healthy, whole, secure, intact, preserved - and salutis - health, security, salutations - and finally salus - health, happiness, luck, preservation, salvation, goodness, wholeness (hence, in archaic Polish, for example, one can "use an escape for salvation"- to rescue himself or herself and to survive thanks to escaping, and to avoid a threat through escaping). In Latin, therefore, security is associated with existence and life without care (more exactly, self-care or any care, control, attention and supervision); with a serene, healthy, whole, good, free, happy, full and even perfect life.

In contemporary philosophical literature, Michel Foucault and his followers conduct an especially epistemologically interesting analysis of the term security, applying semiology and distinguishing multiple layers and aspects. This type of analysis is called biopolitical. According to it, the security epoch in the exercise of power changes the correlates and dominant features of legal and disciplinary mechanisms (see: Foucault, 2010: 31) in the protection of the common interest against individual interests and, on the contrary, the protection of "individual interests against anything that seems to be an expansion of the common interest" (Foucault, 2011: 89). The change of correlates is based on - as mentioned before - liberalism which replaced the notion of rule with the notion of governance, and in which freedom is guaranteed by the state - the governing of the living, including the governing by the means of truth and revelation of truth (see: Rzadzenie, 2014). Hence, the liberal art of governance is entangled with the paradox of freedom and of implementation of control procedures and forms of state intervention (Foucault, 2011: 396). In the pre-liberal system of exercising power, "based on sovereignty, there were, between the sovereign and the subject, numerous economic and legal relations that mobilized or even required the ruler to protect the subjects $[\ldots]$. The subject could request from the sovereign the defense from external or internal enemies. Liberalism has totally different consequences. Providing a kind of external protection directly to the individuals is no longer the purpose. Instead, liberalism launches a mechanism requiring constant measuring out of freedom and security of the individuals in relation to the notion of threat. If, on the one hand, liberalism is an art of governing based on the manipulation of various interests [...] then, on the other hand, it is unable to manipulate those interests without managing the threats and the mechanisms of security/freedom that aim at maximum protection of individuals and communities from the threats" (ibid.: 89-90). The result is "an unprecedented expansion of control, coercion and enslavement procedures that constitute a counterweight to the granted liberties" (ibid.: 91). This proliferation raises the costs of liberal governing which uses instruments such as: 1 . management of threats and of the implementation of security mechanisms (for the protection of common and individual interests); 2. disciplinary control mechanisms (Bentham's Panopticon) - reward, punishment and resocialization or education; 3. policy of interventionism - management of freedom and of crisis into which this policy falls (ibid.: 73-94). In that art - as the thinker asserts - ,The problem of security is the problem of protection of the common interest 
against individual interests. However, to the contrary, individual interests should be defended against everything that seems to be an expansion of the common interest. Also necessary is to make sure that economic freedoms do not threaten the enterprises and the workers, and that the mechanics of interests does not threaten the individual and the community. Freedom and security, the game of freedom and security - this is what we find at the very center of the new organizing mind [...]" (ibid.: 89).

As a conclusion, to reflect the essence of social security, it seems better to set it in the more natural understanding of security as identified with any care, protection and control than to identify social security with the absence of threats. The reason is that leading publications identify social security with protecting the existential foundations of human lives and assuring the fulfillment of individual needs (material and spiritual) and aspirations through the creation of conditions facilitating work and education, and through healthcare and pension guarantees (see: Skrobacz, 2012). In short - with the control and care of citizens. At the same time, deeply justified is the vision of biopolitics in which security implemented through increasing control correlated with economic measures constitutes the essence of liberal-democratic society. The control and the broadening of the protection of the existential foundations of life leads to the inclusion into it of broader and broader social circles and groups, and of more and more people. This inclusion is related to the liberal-democratic tendency toward the universal widening of inclusion processes, especially to cover the existential foundations of people's lives and their living standards. It is a tendency stemming from the Enlightenment idea of equality and brotherhood of people - the idea of equal rights, which in the inclusion processes related to social security takes the form of liberal justice. As formulated by John Rawls, this objective means giving everybody maximum freedom and minimum opportunities, with minimum conditions of existence and living. Without this minimum, realization of maximum freedom is impossible. Therefore - Rawls writes in his A Theory of Justice - "social and economic inequalities require policies aimed at maximum benefits for the most handicapped (the differentiation principle) and the universal access to public offices and positions with genuinely equal chances" (Rawls, 2009).

\section{SOCIAL SECURITY AS PROTECTION AND CONTROL OF LIVING STANDARDS}

Just like there is no human rights outside the state, there is no social security outside it. The contemporary state can and does protect the living standards of citizens. To achieve that, the state must control the standards. As already noted by Aristotle, "For as a body is made up of many members, and every member ought to grow in proportion, that symmetry may be preserved; but loses its nature if the foot be four cubits long and the rest of the body two spans; and, should the abnormal increase be one of quality as well as of quantity, may even take the form of another animal: even so a state has many parts, of which some may often grow imperceptibly; for example, the number of poor in democracies and in constitutional states" (Arystoteles, 2008: 138). 
Contemporary states apply welfare policy and social policy to preserve the proportional and imperceptible expansion of both the poor and the excluded masses. These policies influence the number and quality of citizens and their wellbeing - the demographic and economic dimensions of security. In the perspective of the pursuit of contemporary security, these policies aim at welfare security (mainly living standards, and material and economic security) and social security (mainly consciousness-cultural and identity security, and security pertaining to social stratification and the opportunities of advancement in this stratification). The objective of welfare security seems connected to the prevention of civil wars, rebellions and revolutions which, according to Plato, are caused by "excessive poverty and excessive wealth" while the objective of social security - to the elimination of the lack of freedom that also causes civil wars, rebellions and revolutions. Whereas contemporary liberaldemocratic states realize welfare security through the care of citizens regardless of their material status so that they can actually participate in social life, social security consists in assuring for the citizens the opportunities of development through participation in cultural life, access to public services and education (Jagusiak, 2015: 19-21). People should be included into this life and they should enjoy equal opportunities in the participation in this life. It is universally assumed that welfare security is a condition in which individuals and social groups are free from threats, while social security - a condition in which social subjects are free from threats causing economic and social impoverishment reflected in various kinds of exclusion - the lack, first of all, of Aristotelian spiritual (intellectual) goods, but also of material and somatic ones. Explained differently, as by Barry Buzan and Ole Weaver (Buzan, Weaver, 1998: 121), and other leading scholars of security “... welfare security pertains to the economic aspects of the life of an individual, whereas social security - to social groups and their identities" (Jagusiak, 2015: 20-21). Undoubtedly, material goods are the essence of welfare security, while the essence of social security consists in spiritual (intellectual) goods and somatic goods (that pertain to the condition of the body and to healthcare).

Generally, the goal of social security and welfare security is a situation in which the number and quantity (procreation and education) of citizens do not cause the level of affluence and wellbeing to fall down, and instead they cause growth or, at least, balanced growth. Jeremy Rifkin noted in an interview by Adam Leszczyński for "Gazeta Wyborcza" that there is no contradiction between welfare security and a well-functioning economy. He also elaborated: „You say 'We can/t afford the European dream. Jobs disappear, taxes are too high.' And so on. This is what you continuously hear from Poland's economic liberals. There is no contradiction between a social security system and a well functioning economy. It is not true that nothing exists between the old, statist socialism in the European style and American style capitalism. Both models are equally wrong. You need to reform the systems of social security which are too expensive and not efficient enough. It is possible. Scandinavian countries succeed in that. I just returned from Stockholm. Life is quite good there. The Scandinavians are not a different species of humans. They simply discovered how to do it. One should not surrender to neoconservative propaganda. It is a myth that low taxes and free market mobilized the American economy" (Nie dajcie się, 2005). 
That care of citizens and the assurance of growth, or at least of sustainable development, are addressed in the field of welfare security and social security (see Buzan, 1991: 19-20). In contemporary states, welfare security follows four basic models: liberal, social-democratic, Christian-democratic and East Asian - Confucian (Jagusiak, 2015: 85-103). Assuming that the models are set in modern ideologies, liberalism and models stemming from it prefer individual freedom, social-democratic ideologies and associated models prefer equality, and Christian-democratic ideologies provide the basis for models that prefer social solidarity and mutual love (ibid.: 104-108). Finally, models stemming from Confucianism and Buddhism provide care especially to families while requiring from them, and from employers or local communities, the responsibility for welfare security (see: Jagusiak, 2015: 103). This model prefers selfcare, care of another person and the local community: I-You-We.

At least five variants of those models (individual freedom, equality, social solidarity and mutual love, and family and local love) emerged in European Union countries: Scandinavian, Anglo-Saxon, Continental (Germanic), South European (Mediterranean) and East European models (ibid.: 122-142). Apparently, the Scandinavian model is most similar to the social-democratic model, the Anglo-Saxon model to the liberal model, the Continental model to the Christian-democratic model, and the South European model to both the social-democratic and the Christian-democratic models. The East European model remains in the process of taking shape. It borrows mainly - but not only - from the liberal model and the Christian-democratic model.

Many scholars consider the Scandinavian model to be the most widespread among welfare states. In this model, the state guarantees good living standards, universal systems of healthcare, education, pensions and welfare payments, and a broad choice of public services (ibid.: 128). The Anglo-Saxon model is characterized by state care of working age people and by a broad scope of welfare benefits for the unemployed, while the role of labor unions is limited and the wages are highly diversified (ibid.: 128). In the Continental model, benefits are proportional to the length of employment and to the position on the labor market, while the state does not intervene in the market economy and development processes (ibid.). Deep differences of the levels of welfare benefits and a big role of the Church in welfare activities system characterize the Mediterranean model (ibid.).

The implementation of these models has different effects on the inclusion processes and the limitation of the exclusion of citizens. In many so-called stable democracies in Europe, the inclusion covers not only native citizens but also various immigrants who are included into social life. In the discourse on social security and welfare security in those states, the Gross National Happiness (GNH) indicator appears more and more frequently as an alternative to the modern Gross National Product. The new indicator seems to describe, in an epistemologically interesting way, social and welfare security in the perspective of security which is treated by some people as a contemporary substitute of happiness, because today happiness is an expression of the fulfillment of the social need of security. This indicator is practically used in Bhutan, where it relies on four pillars: 1. sustainable and just socio-economic development which can also be called "ecological development"; 2. protection and promotion of culture, or "cultural security”; 3. protection of the natural environment, or „biosphere security”; 4. good 
management - "good policy" or "appropriate system" (ibid.: 2). Undoubtedly, those pillars can be regarded as the pillars of social security. Hence, they can also be called the pillars of „Gross Social Security.”

Gross National Happiness and „Gross Social Security” with its four pillars (ecological, cultural, environmental and political security) are related to the high ethical and moral quality of citizens, as manifested in the following ten imperatives:

- Giving - to help others;

- Relating - the care of good relations;

- Exercising - the care of psychological and physical condition;

- Appreciating - of the value of the surrounding world;

- Trying out - learning new things;

- Direction - defining appropriate goals;

- Resilience - not to give up in difficult situations (fortitude);

- Emotion - a positive approach;

- Acceptation - self-satisfaction;

- Meaning - a feeling of belonging to something bigger.

In academic lectures, the first letters of the above imperatives constitute the principle (term) of GREAT DREAM (Halvorson, 2013). Undoubtedly, the concept of Gross National Happiness or „Gross Social Security,” as an alternative to Gross National Product, is associated with a crisis or the end of Modernity. It was the conviction of Modernity that mass production brings progress and development. The "Great Dream" at the end of Modernity is related to the replacement of mass production with knowledge and information, as advocated by Alvin Toffler (see: Toffler, 1999) and his followers. Dominance of knowledge and information creates the civilization of the Third Wave, that is, the civilization of knowledge and information (see: Toffler, Toffler, 1997). The vision of this civilization starts with Toffler's observation that the nation state, which for the last three centuries (associated with the Second Wave of mass production and factory production) constituted the basic unit of organization of community life and of the world order, entered a crisis. This is, at the same time, a crisis of "superideologies of the Second Wave," such as liberalism and socialism, of their fascination with Gross National Product, or - in Herbert Marcuse's words - the trap of profit and exploitation, common in the industrial epoch (see: Marcuse, 1991; Marcuse, 1998). The concepts of Gross National Happiness and „Gross Social Security," linked to the ideas of the principle of love, post-market economy and postdevelopment economy (see: Rifkin, 2003), may become a solution to this crisis. If these new concepts are implemented in the spirit of the indicated ideas, then maybe the emerging "... new civilization, as it challenges the old, will topple bureaucracies, reduce the role of the nation-state, and give rise to semiautonomous economies in a postimperialist world. It requires governments that are simpler, more effective, yet more democratic than any we know today" (Toffler, 2006: 36-37). This new civilization will be created by - as Toffler calls them - techno-rebels, characterized by ecological, democratic and humane motivations, are by the pursuit of sustainable development (ibid.: 179). This type of motivations seems to facilitate the expansion of social security, the inclusion of maximum number of citizens into it, and the elimination of areas of extreme poverty and exclusion. 
Numerous problems occur in contemporary efforts to unambiguously define the notion of security. Its meaning can be understood differently both in science and in everyday life. Hence, the notion is ambiguous. It was necessary, therefore, to show how various authors comprehend security, and which aspects of the meaning of this word they focus on. Additionally, the etymological meaning of the word required reviewing and comparing it to the conventional meaning. The result of the conducted analysis is that, in social and humanistic sciences, security in a very general sense comprises the fulfillment of human needs, such as existence, survival, wholeness, identity, independence, peace, ownership, assured development, and protection of the existential foundations of people's lives. It was also established that now the etymological, real and communicative meanings of the word security become increasingly different. The real meaning of security diverges from the derivational and etymological meanings.

Social security, in turn, is identified with care, protection and control, and also with protection of the existential foundations of people's lives and with assured opportunities to fulfill individual needs and to achieve vital objectives through the creation of appropriate conditions. One of its phenomena is welfare security. Four pillars of social security should be underscored (ecological, political, environmental and cultural security). Also very important is the inclusion of the population to social life, so that all people will obtain equal chances of functioning in everyday life.

\section{REFERENCES}

Arystoteles (2008), Polityka, Warszawa.

Brückner A. (1974), Stownik etymologiczny języka polskiego, Warszawa.

Buzan B. (1991), People, States and Fear: An Agenda for International Security Studies In the PostCold War Era, London.

Buzan B., Weaver O., De Wilde J. (1998), Security: A New framework for Analysis, London.

Cackowski Z. (1989), Zasadnicze zagadnienia filozofii, Warszawa.

Długosz-Kurczabowa K. (2010), Bezpieczny i niebezpieczny, in: Słownik języka polskiego PWN, http://sjp.pwn.pl/poradnia/haslo/bezpieczny-i-niebezpieczny;11249.html (4.12.2016).

Drabik K. (2013), Bezpieczeństwo personalne i strukturalne, AON, Warszawa.

Fehler W. (2002), O pojęciu bezpieczeństwa państwa, in: Bezpieczeństwo państw i narodów w procesie integracji europejskiej, (eds.) W. Śmiałek, J. Tymanowski, Torun.

Foucault M. (2010), Bezpieczeństwo, terytorium, populacja, Warszawa.

Foucault M. (2011), Narodziny biopolityki, Warszawa.

Gołaś K. (2013), Pojęcie bezpieczeństwa, Geopolityka.net, http://geopolityka.net/pojecie-bezpieczenstwa (20.05.2018).

Gołembski F. (2008), O wieloznaczności pojęcia bezpieczeństwo, „Nowoczesne Systemy Zarządzania. Zeszyt WCY IOiZ”, No. 3.

Halvorson, H. G. (2013), Jak poczucie szczęścia zmienia się z wiekiem, Obserwatorium psychologiczne, http://www.psychologia.edu.pl/obserwatorium-psychologiczne/1730-jak-poczucieszczescia-zmienia-sie-z-wiekiem.html (5.05.2015). 
Jagusiak B. (2015), Bezpieczeństwo socjalne współczesnego państwa, Warszawa.

Jaźwiński J., Ważyńska-Fiok K. (1993), Bezpieczeństwo systemów, Warszawa.

Jones R. E. (1970), Analysing Foreign Policy: An introduction to Some Conceptual Problems, London.

Kaczmarek J., Skowroński A. (1998), Bezpieczeństwo: świat - Europa - Polska, Wrocław.

Krystyna Dlugosz-Kurczabowa (2016), http://www.krystyna.dlugosz.kurczab.com (19.05.2018).

Liddell H. G., Scott R., Jones H. S. (1996), A Greek-English Lexicon, 9th ed., Oxford.

Lisiecki M. (2008), Diagnoza i prognoza rozwiazań systemowych w zakresie organizacji i zarządzania bezpieczeństwem obywateli, in: Zarządzanie bezpieczeństwem - wyzwania XXI wieku, (ed.) M. Lisiecki, Warszawa.

Marcuse H.(1991), Człowiekjednowymiarowy. Badania nad ideologia społeczeństwa przemysłowego, Warszawa.

Marcuse H. (1998), Eros i cywilizacja, Warszawa.

Nie dajcie się nabrać Ameryce. Rozmowa A. Leszczyńskiego z J. Rifkinem (2005), „Gazeta Wyborcza", 17.11.2005.

Bezpieczeństwo systemów informatycznych (2006), (eds.) A. Niemiec, J. S. Nowak, J. K. Graba, Katowice.

Nye J. S., Keohane R. (1977), Power and Interdependence: World Politics in Transition, Boston.

Nye S. (2009), Konflikty międzynarodowe. Wprowadzenie do teorii i historii, Warszawa.

Rawls J. (2009), Teoria sprawiedliwości, Warszawa.

Rifkin J. (2003), Koniec pracy. Schytek siły roboczej na świecie i początek ery postrynkowej, Wrocław.

Roosevelt F. D. (2006), Cztery wolności, in: Wielkie mowy historii, Vol. 3: Od Hitlera do Eisenhowera, (ed.) M. Gumkowski, Warszawa.

Rosa R., Lipińska-Rzeszutko M., Kubiak M. (2010), Filozofia bezpieczeństwa personalnego i strukturalnego. Tradycje. Wspótczesność. Nowe wyzwania, Siedlce.

Rządzenie żywymi (2014), Warszawa.

Skorupka S. (1985), Stownik frazeologiczny języka polskiego, Warszawa.

Skrobacz A. (2012), Bezpieczeństwo społeczne. Pojęcie, uwarunkowania, wyzwania, Warszawa.

Stownik angielsko-polski, https://translate.google.pl/?hl=pl.

Stownik grecko-polski, https://translate.google.pl/?hl=pl.

Stownik terminów z zakresu bezpieczeństwa narodowego (1996), Biuro Prasy i Informacji MON, Warszawa.

Stańczyk J. (1996), Współczesne pojmowanie bezpieczeństwa, Warszawa.

Stańczyk J. (1999), Bezpieczeństwo i pokój - wzajemne relacje, in: Edukacja dla bezpieczeństwa i pokoju w jednoczacej się Europie. Teoria i jej zastosowanie, (ed.) R. Rosa, SiedlceChlewiska.

Stańczyk J. (2006), Poszukiwanie reguł definiowania bezpieczeństwa, „Studia Bezpieczeństwa Narodowego. National Security Studies", No. 10.

Świniarski J. (1997), O naturze bezpieczeństwa. Prolegomena do zagadnień ogólnych, WarszawaPruszków.

Świniarski J. (2013), Barwy w pogłębianiu i poszerzaniu badań nad bezpieczeństwem, in: Barwy i cienie bezpieczeństwa, (ed.) W. Gocalski, Warszawa.

Toffler A. (1999), Nadciaga czwarta fala, „Polityka”, 25.12.1999.

Toffler A. (2006), Trzecia fala, Poznań. 
Toffler A., Toffler H. (1997), Wojna i antywojna. Jak przetrwać na progu XXI wieku, Warszawa.

Zięba R. (1999), Instytucjonalizacja bezpieczeństwa europejskiego: koncepcje - struktury - funkcjonowanie, Warszawa.

Zięba R. (2012), O tożsamości nauk o bezpieczeństwie, „Zeszyty Naukowe AON”, No. 1.

\begin{abstract}
The article presents and analyzes selected basic problems coinciding with the issues of the inclusion and integration of population into the domain of social security, and it answers the research question: what is the proper, complete and exact meaning of the notions of security, social security, and social welfare? Critical semantical analysis of many works and statements, from classical to modern to newest ones, is the principal research method. According to the central conclusion, the most proper definition of social security identifies it with care, protection and control and not mainly with the absence of threats. The author underscores that leading publications identify social security with protecting the existential foundations of human lives and assuring the fulfillment of individual needs (material and spiritual) and aspirations through the creation of conditions facilitating work and education, and through healthcare and pension guarantees. Part One of the article focuses on the etymology of the definition of security, and on the conventional understanding of security. Part Two is devoted to the natural definition of security, especially social security. Part Three provides information on the topic of social security, considered from the angle of protection and control of people's living standards.
\end{abstract}

Keywords: inclusion, security, society

\title{
ZASIĘG BEZPIECZEŃSTWA SOCJALNEGO W PROCESACH INTEGRACYJNYCH
}

\section{STRESZCZENIE}

Artykuł przedstawia i analizuje wybrane podstawowe problemy związane ze sprawami włączenia i integracji ludności w dziedzinie bezpieczeństwa społecznego. Odpowiada na pytanie badawcze: jakie jest najbardziej właściwe, pełne i dokładne znaczenie pojęć bezpieczeństwo, bezpieczeństwo społeczne i bezpieczeństwo socjalne? Główną metodę badawczą stanowi krytyczna analiza semantyczna wielu prac i wypowiedzi, od klasycznych do modernistycznych i najnowszych. Główny wniosek brzmi, że najwłaściwsza definicja bezpieczeństwa społecznego wiąże je z troską, ochroną i kontrolą, a nie przede wszystkim z brakiem zagrożeń. Autor podkreśla, że czołowe publikacje utożsamiają bezpieczeństwo społeczne z ochroną egzystencjalnych fundamentów życia ludzi oraz zapewnianiem zaspokojenia indywidualnych potrzeb (materialnych i duchowych) i aspiracji poprzez tworzenie warunków sprzyjających pracy i edukacji, i poprzez ochronę zdrowia i gwarancje emerytalne. W pierwszej części artykułu zawarte zostały treści poświęcone etymologii definicji bezpieczeństwa i jego konwencjonalnego pojmowania. Część druga poświęcona została tematyce naturalnego definiowania bezpieczeństwa, a w szczególności bezpieczeństwa społecznego. W części trzeciej umieszczono informacje poświęcone zagadnieniu bezpieczeństwa społecznego, które ujęte zostało przez pryzmat ochrony i kontroli warunków bytowych ludzi.

Słowa kluczowe: włączenie, bezpieczeństwo, społeczeństwo 